\title{
Referenda and their impact on the future of a united Europe. Brexit and the shape of the European Union
}

\section{Introduction}

The experience gathered in the field of direct democracy exercised in European states evidences that, alongside frequent referenda organized on national topics, EU issues are becoming an increasingly popular subject of public debate followed by voting. Using national referenda for the purpose of making decisions on the process of European integration is not a novelty. The first such vote took place as early as in 1972. Since then, different aspects of European integration have been put to sixty national referenda in member states, candidate countries as well as in third countries associated with the European Union through various bilateral agreements (Switzerland and Liechtenstein). The experience related to the referenda on 'European' matters has largely been positive, but some referenda have been troublesome for member states and the EU.

Among the most recent examples of referenda whose consequences will be reflected in the future shape of the European Union is the vote on the UK's membership of the European Union, held on June 23, 2016. The negative result of this referendum (similarly to the results of several other referenda on deepening European integration, held in Greece and Denmark, among others) is indicative of the increasing skepticism of European nations about integration processes in the Old Continent. This may be the outcome of the financial crunch Europe has been struggling with since 2008, as well as of the refugee crisis the EU seems unable to resolve. These difficulties are augmented by the economic migration from new EU members to selected states of the 'old 15,' which often translates into the 'resistance' of countries that receive the immigrants.

The considerations defined in the title of this paper are inspired by the topicality of the subject of the referendum held in the UK and the fact that referenda have recently become a popular instrument used in order to make decisions on the crises of the EU and thereby on its future (which this paper argues).

The main objective of this paper is to answer the question of the outcomes of referenda (with special emphasis given to the vote in the UK) for the future shape of the European Union. In terms of methodology, this paper will apply an institutional-legal method, which is useful in the analysis of the regulations pertaining to the instrument of international referendum. Additionally, a system analysis will be used alongside the genetic historical method, allowing the researchers to examine the history of referenda in the process of European integration and in the UK. The analysis of statistics will be helpful when examining the results of votes, among other things. 


\section{Direct democracy and making decisions on European integration}

The analysis of the institutional solutions employed by the European Union makes it clear that the system of political bodies in the EU and all its member states relies on solutions typical of representative democracy. The core governance mechanism in a representative democracy is provided by elections. This form of democratic governance is frequently complemented by elements of direct democracy, which is about enabling eligible voters to make decisions on crucial matters through referenda and common initiatives. By this token, citizens exercise their influence on the political agenda.

The majority of EU states have been combining the solutions typical of both forms of democracy (with a greater proportion of those of representative democracy, of course). Vesting the decisions on a variety of matters in citizens is justified by the need to make them more involved in the processes of political decision making, which may reverse the crisis of a representative democracy that has attracted so much attention recently. Resorting to direct democracy at EU level is frequently justified by the need to eliminate the 'democratic deficit' (Koruba, 2017).

Almost since the beginning of European integration within the Community, European structures have been criticized for their lack of democratic procedures when forging European policies, and for the lack of transparency of decision-making procedures, and thereby - for generating that democratic deficit (Klaus, 2004, pp. 53-71). In this context, scholars point to the distance between the citizens of the European Union, which is described as a "unique democratic experiment" (Hautala, 2010, p. 5), and its institutions, and primarily to the fact that citizens are neither aware of, nor familiar with how they can become involved and what influence they may have on the debates and decisions taken on the European level (Capik, 2017).

It is worth making reference to Michael Nentwich here, who associates the democratic deficit which civil participation in the political system of the EU. By introducing such terms as opportunity structures for citizens' participation - OSCPS (different channels of access for citizens to the public sphere and to the processes that shape and implement policies) and political opportunity structures - POS (aggregated OSCPs present in a given political system) Nentwich argues that the European Union "offers its citizens extensive opportunities to participate in governance and decision making" (Mizera 2014, p. 96; cf. Nentwich, 1998; Nentwich, 1996; Kitschelt 1986, pp. 58, 61). Therefore, direct democracy appears to be one solution to the above-mentioned problems, claims Bruno Kaufmann, an advocate of solutions based on direct democracy and the president of the Initiative and Referendum Institute Europe.

It should be noted that criticism of the EU instigates efforts to consistently launch "broader public debate, more effective civil dialogue and greater political awareness" and thereby "enhance representative democracy and participatory democracy" (European Parliament resolution of 13 January 2009).

The Lisbon Treaty provided for the mechanism of the European People's Initiative, which was intended to enhance the democratic structures of the European Union. Yet the experience of using this instrument allows us to note that it has not been enthusiastically adopted by Europeans, which is likely to have been caused by the 
complicated procedure of collecting signatures and, primarily, by the requirement to collect a minimum of one million votes of EU citizens from a minimum of $25 \%$ of all EU member states, while observing certain minimal quotas for individual countries (Capik, Gniewek, 2012, p. 39). The ten years of the presence of this instrument of direct democracy have not seemed to indicate that it has achieved the intended goal of reducing the deficit of democracy, and thereby the distance between EU citizens and EU institutions.

Over the same period, direct democracy and its instruments, referenda in particular, have become increasingly popular both among citizens who want to have a greater influence on their state and local policies and among those in power who let eligible voters make different (sometimes awkward) decisions.

It should be noted that the increased interest in the instruments of direct democracy in Europe results from the nature of the political transformations that have been experienced by the states in the Old Continent. The more frequent resorting to different forms of direct democracy is witnessed both in Western Europe and in Central and Eastern Europe. The common denominator for these two groups is the process of European integration, which has been and continues to be the subject of numerous referenda held in different contexts in EU member states and in third counties which maintain all kinds of contacts with the EU.

As has already been indicated, in terms of the number of referenda held, the process of European integration is among the most frequently voted issues in the world. The first of the nearly sixty votes took place in France on April 23, 1972, and concerned the issue of the ratification of the accession treaties allowing the UK, Denmark, Ireland and Norway to enter the European Community (Sutton, 2011, p. 184). ${ }^{1}$

The referendum, called on the initiative of President Georges Pompidou, was followed by a further three referenda (including two with a positive result) on the accession of Ireland, Norway (negative) and then Denmark respectively. ${ }^{2}$ The first 'European' referendum in France initiated the wave of referenda on the unification of European states and marked a significant turning point in the process of making decisions on the future of the Old Continent.

A detailed analysis of the referenda held on different aspects of the integration processes, enhancing integration and expanding the group of EU member states, evidences the fact that direct democracy has become an important instrument in making decisions that have an influence on the future of the countries that hold these referenda, but also on the future of a united Europe. The number of national referenda carried out on the matters related to a varying extent to European integration is a clear indicator of the significant role direct democracy plays in shaping integration processes (Musiat-Karg, 2012, p. 210). The instrument of national referenda has become one of significant ways for member states (or, more exactly, for eligible voters) to express their opinions on the matters concerned, which in this case often pertain to supranational issues. "EU member states and a handful of third countries (which are not EU members but maintain a wide variety of relations with the EU, for instance

${ }^{1}$ On April 5, 1972, by virtue of Article 11 of French Constitution, President Pompidou issued a decree on the referendum to be held on the topic of the enlargement of European Communities.

2 The UK did not employ the instrument of a referendum before accession. 
by virtue of the Schengen Agreement) have repeatedly used referenda to forge EU structures, determine the conditions and directions of integration policy in Europe. All 'European' referenda can be divided into several categories with respect to their topic" (Musiał-Karg, 2012, p. 210).

Category one encompasses referenda held on broadly understood issues of EU membership and accession. It contains all the referenda where the citizens of member or candidate countries were asked about accession to, or further membership of the Community. The French referendum of April 23, 1972, where the French expressed their approval for the enlargement of the EC, does not fall into this group. This is because the subject of this referendum did not concern France's membership, but the enlargement of the EC. Referenda held on the topic of whether the procedure of applying for the status of candidate country should be commenced (e.g. Swiss referenda) are also excluded. A total of twenty-five referenda on EU membership have been conducted since 1972: five - on the accession to, or membership of the EC, one - on joining the EFTA, three - on the membership of the European Economic Area (EEA) and sixteen - on the accession to, and further membership of the EU. This group of general votes included both UK votes on membership of the EC (1975) and of the EU (2016).

Another group comprises the referenda on approval for the ratification of European treaties. There are sixteen votes in this group: two votes on a Single European Act (SEA), ${ }^{3}$ four on the Maastricht Treaty, two on the Amsterdam Treaty, two Irish referenda on the Nice Treaty and another two on the Lisbon Treaty, and four referenda on the ratification of the Treaty establishing a Constitution for Europe.

Group three is composed of nineteen referenda on topics other than the abovementioned matters of importance for European integration, and encompasses the following: the 1972 French referendum on the enlargement of the EC, the 1989 Italian referendum on the legitimization of the European Parliament, two Swiss referenda on applying for EU membership, five referenda on different bilateral agreements with the EU (including the regulations pertaining to the Schengen Agreement), Danish and Swedish referenda on the adoption of the single euro currency, the Romanian referendum conducted in order to amend the Constitution on account of approaching accession to the EU, and the 2012 Irish referendum on the adoption of the fiscal pact. This category also embraces the 2014 and 2015 referenda held in Denmark on the accession to the Unified Patent Court, and on the enhancement of collaboration in the field of the judiciary and internal matters respectively, the 2013 San Marino referendum on submitting a motion to join the EU, the negative 2015 Greek referendum on accepting EU financial aid, the Dutch referendum on agreement to ratify the accession agreement between the EU and Ukraine and, last but not least, the Hungarian vote on approving the obligatory refugee quota.

The above categorization on the basis of the topic of the vote leads to the conclusion that two types of issue prevail in the referenda on the process of European integration: first, the issue of EU membership and accession to the EU and, second,

${ }^{3}$ Since the referenda on the EEA are directly related to the single European market, they could be included in the third group of referenda on various European issues. As these votes concerned the treaty, which constitutes the primary law of the EU, they were included in the second category. 
agreements to ratify EU treaties. It should be noted that the European Union is discussing the matter of whether referenda are the appropriate instrument for making decisions on issues as complicated and complex as the treaties. Experience shows that votes on the treaties tend to be negative more frequently than the remaining types of referenda, as evidenced by the Irish votes (on the Nice Treaty and Lisbon Treaty), and the French and Dutch referenda on the Treaty establishing the Constitution for Europe (Kużelewska, 2011).

Analyzing the topics of the referenda, it is worth noting that the process of European integration has contributed to the emergence of a somewhat new type of voting, namely, referenda on accession. The vast majority of EU member states vested the matter of their prospective membership in the electorate, before they officially joined EU structures. It has practically become a principle to precede EU enlargements by accession referenda in most candidate countries. It has not always been the case, however. Such votes did not take place in the UK (although the continuation of membership was voted on two years after accession to the Community), Greece, Spain, Portugal and - before the greatest enlargement - in Cyprus, Romania (where the referendum addressed the alignment of the Constitution with Romania's further EU membership) and Bulgaria. The decisions in those countries were taken exclusively by their respective parliaments. The results of accession referenda were not necessarily formally binding in every country. Due to the exceptional importance of EU membership, however, in the majority of countries that decided to refer to the opinion of their citizens, the governments have customarily followed the standpoint expressed by voters in the referenda (Referenda akcesyjne na Malcie, w Stowenii...; Musiał-Karg, 2012, p. 212).

The analysis of all the referenda held on the topic of European integration indicates that they remain popular and that, despite the difficult experience of 'lost' referenda from time to time, the governments of individual EU member states submit quite a number of issues to civic vote. This is evidenced by the statistics showing that more than half of all EU votes have occurred over the last fifteen years: thirty-three referenda have been held since 2001. These numbers demonstrate that integration processes in Europe are very intensive and that individual states are willing to transfer common EU matters to their citizens.

It should be noted that eight referenda have had a negative result, thereby generating numerous conflicts the EU has faced, for instance the lost 2005 votes in France and the Netherlands, the negative result of the Irish referendum on the Lisbon Treaty in 2008, the 2015 referendum in Greece on accepting EU financial aid intended to help Greece overcome the financial crisis, and, last but not least, the British vote on Brexit.

Studies on the instrument of referenda being employed in the process of 'European' decision making show that some EU member states have never resorted to direct democracy with reference to the issues of European integration, namely Belgium, $\mathrm{Cy}-$ prus, Germany, Portugal and Bulgaria.

Speaking about those EU member states that have held the most of referenda, Ireland and Denmark come first. There have been nine referenda in each; Ireland had two votes on the Nice Treaty and Lisbon Treaty each; Denmark voted on the Maastricht 
Graph 1. The number of referenda on European integration in different states (1972-2017)

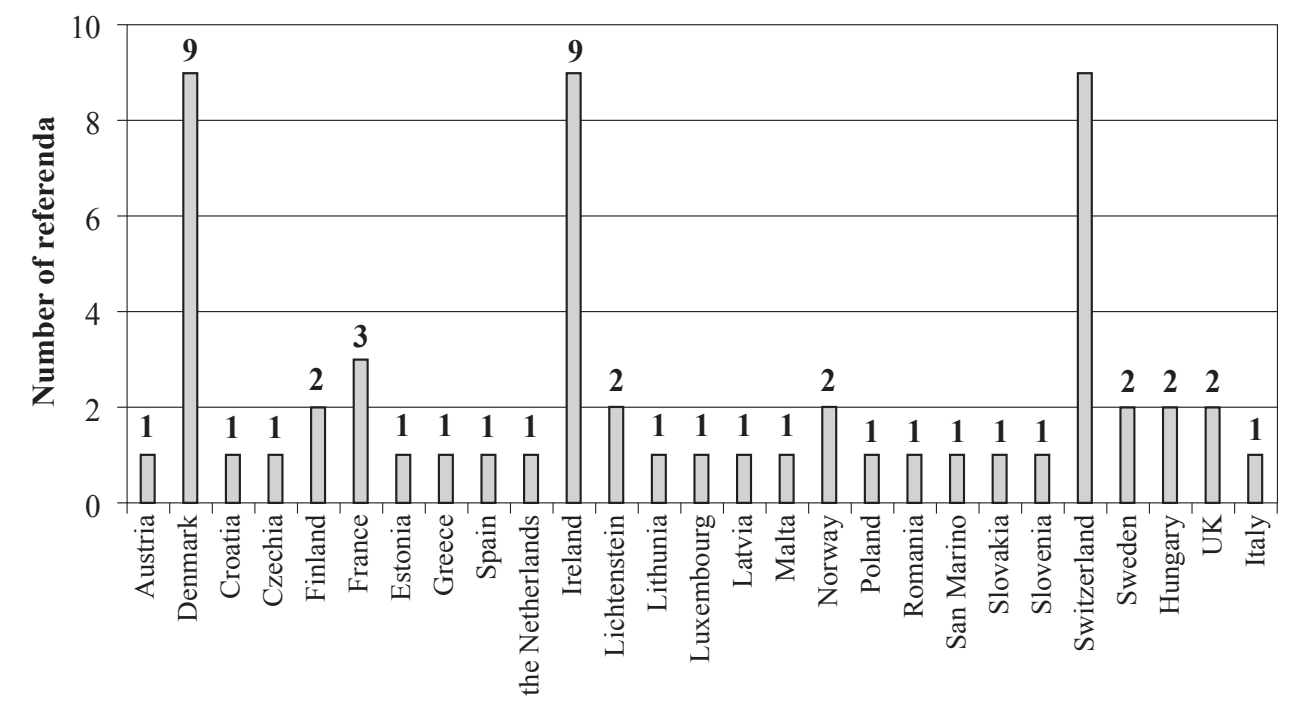

Source: Own elaboration.

Treaty twice. ${ }^{4}$ Ireland is the EU member state where practically all EU matters are put to referenda (as required by the Constitution). Denmark has also adopted the principle that the matters of EU integration should be solved by the citizens via referenda. Graph 1 above, though, demonstrates that Switzerland is the leader in direct democracy as far as European matters are concerned; although not an EU member, it has a broad range of relations with the Union. Matters of enhanced collaboration with the EU and its details are decided via a general vote in the Swiss Confederation. The practice of holding referenda rather frequently there may be explained by the fact that the institutions of direct democracy are the most developed in Switzerland, and this country is named 'the pearl of direct democracy'. It is worth noting that nearly half of all referenda on the topic of integration have been held in the above three countries, one of which is not an EU member.

Speaking about the outcomes of the decisions made on the matters of European integration, referenda can be divided into those related to enlargements (resolving to increase the number of member states, mainly accession referenda) and those related to the 'deepening' ' of European integration (organized in order for the societies of respective EU member states to take a stand on the matter of reforms that enhance integration process) (Szymczyński, 2007, p. 240; Szymczyński, 2010, pp. 133-150; Szymczyński, 2008).

${ }^{4}$ In both countries the first votes on the above-mentioned treaties brought a negative result. Another vote was called in each, following an intensive referendum campaign and the renegotiation of conditions (e.g. Danish opt-outs from the Maastricht Treaty).

${ }^{5}$ It should be noted that such a vote is not a legal term but seems highly useful as a concept of political science in the analysis of EU referenda in terms of political science. 


\section{Historical decision of the British. The referendum on Brexit}

The British referendum on further EU membership was held on June 23, 2016, and can be deemed to have become a turning point for both the UK and the whole of the EU.

The 2016 vote was the second referendum on British involvement in the European integration project. In 1975, two years after the UK officially joined the EC, the British put the matter of their membership to a referendum whose result was negative for the advocates of Brexit at the time. ${ }^{6}$

The United Kingdom has always been known for its Euroskepticism, which has been greater than in the remaining member states, and evidenced by the continuous discussions on possible withdrawal from the European project. Leaving the Community was first considered only one year after the UK joined it. In 1974, Prime Minister Harold Wilson met his electoral promises, announcing the renegotiation of membership conditions (Balsom, 1996, p. 211). Wilson's decision to hold the referendum was additionally justified by economic indicators growing weaker (high inflation and high unemployment), the exacerbation of the conflict in Northern Ireland and the uncertain political situation (Brexit: Ale to już byto..., 2016). On June 5, 1975, the first national referendum was held in the UK (Musiał-Karg, 2008, p. 102; Kużelewska, 2006, p. 103), asking the question of "Do you think the UK should stay in the European Community (Common Market)?" to which a majority (over 67\%) out of $64.03 \%$ of eligible voters in Britain answered "Yes" (1975: UK embraces Europe in referendum). England, Scotland, Wales and Northern Ireland all opted for continued membership of the EEC and further integration of the UK with the remaining eight member states. Prime Minister Harold Wilson said that the result of the referendum was a "historical decision." After this vote, voices could be heard that this decision concluded the matter of the position of the UK in a uniting Europe. On April 9, 1976, the Parliament put this matter to its own vote and confirmed the standpoint of the British. "Promoters of integration celebrated their victory, whereas Euroskeptics from the Labour party declared to accept the results of the plebiscite. The conservative MP Enoch Powell was among the few who deemed the result of the referendum to be temporary" (Sikorski, 2016).

Forty years later, Powell turned out to have been right. Faced by the financial crisis, problems in eurozone, the refugee crisis and difficulties in the Schengen zone the British became even more dissatisfied, and their opposition to EU policies intensified further.

It should be noted that the standpoint of the UK frequently expressed its Euroskepticism. Paweł Stawiski refers to the studies by NGO VoteWatch, which examines how European politicians vote, and indicates that from July 2009 to March 2015 "the UK

${ }^{6}$ British experience with referenda is highly limited. A total of three nationwide referenda have been held there so far:

- on further membership of the European Economic Community in 1975;

- on changes to the election of deputies to the House of Commons of May 5, 2011. The referendum was concluded by a negative result: given voter turnout of $42.2 \%, 68 \%$ of voters said "No" to the referendum question;

- on further membership of the European Union of June 23, 2016. 
was most often in the minority in the votes taken in the European Council by ministers representing member states. British government was in the opposition in 85 out of 680 votes [...] In the period under consideration, the European Council held 67 votes on the budget and the allocation of EU money. London was in the minority on 23 occasions, which is more than any other member state [...] Out of 43 votes on agriculture, the UK was in the minority eight times [...] The British repeatedly expressed their opposition to different initiatives under the common foreign and security policy. Out of 15 votes on this topic, London was in the minority on seven occasions" (Stawiski, 2015).

Thus, Euroskeptical attitudes had long been present in the activities of the British Government, and Prime Minister David Cameron's electoral promise was his response to the increasing criticism of the steps taken by the European Union voiced by the Euroskeptical wing of the Conservative party which threatened rebellion. Another significant factor which should be mentioned here concerned the consistently growing popularity of the anti-EU UK Independence Party (UKIP) of Nigel Farage, and the Conservatives' concerns with the result of the upcoming elections. Wioletta WilkReguła rightfully notes that another factor was the growing number of citizens who were reluctant to finance poorer member states (Wilk-Reguła).

Cameron was of the opinion that "Europe has changed tremendously" since the UK had joined the European project. "Even if the referendum did not take place now [in 2016 - M.M-K] it would have to be held in the future." In an interview given to the Financial Times, Prime Minister stated that the referendum would ultimately settle the matter of British membership and would be decisive, regardless of the result. $\mathrm{He}$ stressed the fact that if the society voted to leave the EU, this decision would be irreversible. This statement was interpreted as a warning to Euroskeptics in the Conservative Party (Cameron zostat zmuszony..., 2016).

Cameron's decision to hold the referendum may be interpreted in terms of shifting the responsibility for the historical decision to the citizens. It is also worth noting that "apart from the fact that the declaration to hold the referendum kept recurring in the EU talks, it was also inscribed in The Conservative Party Manifesto 2015 and announced by Queen Elizabeth II in her speech delivered on May 27, 2015 (Queen's Speech 2015 EU). According to some political commentators, when Cameron opted for the referendum to be held he "unwisely took the referendum bait" (Stara dobra pulapka referendum, 2013). The Prime Minister assumed that the threat of the referendum and potential Brexit would force the European Union to grant special rights to the UK which would curb the demands of the advocates of Brexit (Łada, 2016, p. 12).

Examining the relations between the UK and EU, it becomes apparent that the British 'anti-EU sentiments' are far from being a novelty, since for a long time the British "have remained one of the most Euroskeptical nations in the European Union and successive UK governments were adamant in placing British interests over the benefits of the Community" (Piotrowicz, 2015). These Euroskeptical sentiments, manifested by the UK's threats to exit the Community, intensified particularly in the times of crises in the EU. Such a stance taken by successive British governments was a kind of a tactic intended to coerce the states of the Community to offer better conditions to the UK (Musiał-Karg, Lesiewicz, 2015, pp. 117-119). 
The date of the referendum on continued UK membership of the EU was set in the circumstances of the long-lasting financial crisis, enormous problems in Greece and the threat of Grexit, which was even further exacerbated by the refugee crisis. The referendum planned by Cameron and its potential negative results posed another huge problem for EU leaders to tackle. For nearly one year, multilateral talks were held to establish the future formula of European integration and the reform in the Community that Cameron's government demanded (Korteweg, 2015).

In February 2016, an agreement on the future UK membership of the EU and the British plans to revamp the Community was reached after long and complicated negotiations. By virtue of this compromise the UK was to be excluded from an 'increasingly united Union'. The UK was also allowed to introduce a partly limited access to the non-contributory in-work benefits for migrants from the EU (Sondaż: znaczny skok poparcia..., 2016). In Cameron's opinion this compromise was an argument helping those disheartened about the EU to change their opinion and vote against Brexit in the upcoming referendum (Porozumienie UE z Wielka Brytania, 2016; Unię Europejska czeka Brexit?, 2015).

Based on this compromise, and on the basis of opinion polls (e.g. Ipsos MORI ${ }^{7}$ ), it could have been assumed the citizens of the UK would opt for the continuation of UK membership of the UK, whereas the government in London appeared to intend to take measures in order to enhance "the stability of the EU, the single market and eurozone, although remaining outside the mainstream of deepened collaboration. This stance may additionally support the tendencies to implement a "two-speed Europe"" (Biskup, 2013, p. 52-53; Musiał-Karg, Lesiewicz, 2015, p. 119), as confirmed by the actions of David Cameron, who supported the 'cafeteria' model of integration where member states collaborate within the areas they find 'convenient' for themselves.

As declared, on June 23, 2016 a national referendum was held asking the British the following question: "Should the United Kingdom remain a member of the European Union or leave the European Union?"

On the following morning, the Chair of the Electoral Commission, Jenny Watson announced that the British had chosen Brexit. With turnout at a level of $72.2 \%, 48.1 \%$ of voters (16.1 million persons) supported staying in the EU, whereas 51.9\% (17.4 million voters) voted for Brexit. The voters in Scotland and Northern Ireland opted for further integration, while $53.5 \%$ of voters in England and $52.5 \%$ in Wales opted for Brexit (Musiał-Karg, Lesiewicz, 2015, p. 119).

The first outcomes of the referendum results could be seen immediately after the vote. Considerable drops were recorded in stock markets the following day, and the situation was reflected in the British pound losing value (Brytyjski minister: becdzie plan awaryjny). As concerns political consequences, apart from the decision to exit the EU, one of the most important short-term consequences involved the resignation of Prime Minister David Cameron. He stepped down, claiming that the Brexit negotiations should be conducted by a new head of government. Cameron remained the leader of the Conservative Party until Theresa May was elected to this position on July

${ }^{7}$ By mid-2015, the numbers of advocates of further membership appeared to be greater than its opponents. In the third quarter of 2015 support for the UK remaining in the EU dropped to ca. $50-51 \%$ and remained at this level until the referendum in June. 
13, 2016. She was appointed the new British Prime Minister on the same day as party leader (David Cameron says being PM 'the greatest honour'..., 2016). On September 12, 2016, David Cameron stood down as MP to the House of Commons with immediate effect (David Cameron zrzeka się mandatu, 2016).

Describing how she sees the British exit from the European Union, Theresa May said in January 2017 that she would do her best to work out "the best possible agreement" and that the UK would introduce new immigrant legislation, leave the EU single market and the customs union (Premier Wielkiej Brytanii zdradziła scenariusz Brexitu..., 2017).

Two weeks after the House of Commons supported Brexit on March 13, 2017 (Parliament passes Brexit bill..., 2017), "[o]n 29 March 2017 the UK formally notified to the European Council its intention to leave the EU and the European Atomic Energy Community (Euratom)" (Rada Europejska (art. 50)..., 2017). This triggered Article 50 of the Lisbon Treaty which officially commenced the process of negotiations on the UK leaving the EU. The UK has two years to negotiate the best possible conditions of leaving the EU. The negotiation process is likely to be demanding and complicated for both parties: the British government and the European Union alike.

\section{Referenda and European integration process - concluding remarks}

Resorting to the instrument of referendum in order to make decisions on national matters is a popular (albeit not very frequent) means of decision making in European states. Switzerland is probably an exception here, since it employs the instruments of direct democracy at least several times a year and resolves both domestic and international matters in this way.

The process of European integration is a highly interesting issue which appears to be the only one that is so frequently and repeatedly put to referendum in Europe. From 1972 to the end of 2016, sixty votes on European matters were held across nearly all EU member states, as well as in several other countries.

The considerations presented in this paper make it possible to draw several conclusions on the role of referenda in the process of integration, and the influence referenda results have had on the process of European integration:

- first, Europe is a pioneer both in terms of the number of votes and the number of states holding referenda on a single, broad issue. EU referenda have been held in twenty-seven countries, including four outside the EU;

- second, as has already been mentioned, many referenda on integration have had an enormous impact on the shape of a united Europe, translating both into the enlargement of the group of EU members and enhanced collaboration within the EU. One of the outcomes is likely to involve the reinforcement of the instrument of referendum, which has been employed with reference to the accession of the majority of EU member states;

- third, the analysis of turnout makes it possible to observe that voters are eager to take part in referenda on EU matters (frequently more eager than is the case with other domestic votes). The average turnout in all votes taken on the process of inte- 
gration is relatively high, amounting to $63.95 \%$ and evidencing considerable voter involvement in European decision-making processes (Musiał-Karg, 2014, p. 84) as well as a strong legitimization of the decisions made in this way;

- fourth, 'European' referenda exert a considerable impact on the future of integration as well as on the political and economic matters in the Old Continent. More than once referenda have been decisive in blocking some important reform projects in the EU (for instance, the French and Dutch "No" prevented the Treaty establishing the Constitution for Europe from being ratified). The referenda in Norway and Sweden have blocked their accession or the start of accession negotiations with the EU;

- fifth, recent years have demonstrated that referenda are a tool employed when the EU witnesses crises. Referenda have been used by different governments to make some crisis-related decisions, as concerns both the financial crunch and the refugee crisis. Greek Prime Minister Alexis Tsipras sought to strengthen his negotiating position with EU institutions granting aid to Greece, and resorted to a referendum the result of which could have easily been predicted. ${ }^{8}$ Faced by the refugee crisis, in October 2016, the Prime Minister of Hungary, Victor Orbán held a referendum on the agreement for the obligatory quotas of refugees (imposed by the EU). Despite the low turnout, the result of the referendum was unequivocal - ca. $98 \%$ of voters were against the quotas. Orbán announced that the referendum result would not only provide a point of reference in the talks with Brussels, as it was stated in the referendum campaign, but it would be included in the Constitution of Hungary;

- six, decisions made by holding national referenda may contribute to crises emerging in the EU as exemplified by the British referendum on Brexit of June 23, 2016. It is highly important that the decision made in the British vote has had an influence on the future of UK citizens as well as all the 500 million EU citizens. The British referendum can be deemed as a historic vote for both the British, who decided to withdraw from the process of integration after forty-three years, and for the EU the sense of which has just been questioned by one of the more 'difficult' project participants;

- seven, the British referendum clearly inspires concerns of a domino effect and the possible exits of other EU member states that are discontented with the policies implemented by the Union. "One state withdrawing from EU structures may trigger further exits. This in turn may question the sense of further enhancement of the collaboration in Europe" (Musiał-Karg, Lesiewicz, 2015, p. 126).

In conclusion, it should be emphasized that the changes brought primarily (although not exclusively) by the British referendum, and also by other referenda where EU citizens expressed their skepticism about the EU, are likely to demonstrate a qualitative change as concerns the model and vision of integration in contemporary Europe. The recent events associated with the refugee crisis and Brexit seem to be indicative of the fact that the European Union will become a Union of multiple speeds and differentiated integration may solve (at least partially) the problems of the Community. If this model is implemented, an EU core is likely to emerge, involving a group of countries

${ }^{8}$ The Greek did not want to 'tighten their belts' and implement austerity measures that would reduce salaries. Therefore, they rejected the aid package which was the topic of the referendum. As a consequence, an even more strict package agreement was signed than the one voted on. 
that will take part in all activities, accompanied by EU states participating only in selected projects.

The above description of the employment of the instrument of referenda in the process of European integration is far from exhaustive. Nevertheless, it makes it possible to showcase how complex and multifarious the consequences of using direct democracy are for the process of making decisions with supranational results. It should be borne in mind that the referenda on the process of European integration were national votes which frequently produced results that brought consequences not only for the given country, but also for the entire EU and all its member states.

\section{Bibliography}

1975: UK embraces Europe in referendum, http://news.bbc.co.uk/onthisday/hi/dates/stories/june/6/ newsid_2499000/2499297.stm, 22.08.2017.

Balsom D. (1996), The United Kingdom: constitutional pragmatism and the adoption of the referendum, in: The Referendum Experience in Europe, eds. M. Gallagher, V. Uleri, Londyn.

Biskup P. (2013), Integracja czy dezintegracja? Przyszlość Unii Europejskiej z perspektywy brytyjskiej, "Analiza Natolińska”, nr 5 (63).

Brytyjski minister: będzie plan awaryjny, http://tvn24bis.pl/ze-swiata,75/george-osborne-uspokajanasza-gospodarka-jest-silna,656340.html, 27.08.2017.

Brexit: Ale to juz byto - referendum w 1975 r., 23.06.2016, http://superbiz.se.pl/wiadomosci-biz/ brexit-ale-juz-bylo-referendum-w-1975_855622.html, 26.08.2017.

Cameron zostat zmuszony do referendum ws. Brexitu, 22.06.2016, https://www.salon24.pl/ newsroom/717811,cameron-zostal-zmuszony-do-referendum-ws-brexitu, 25.08.2017.

Capik A. B. (2017), Inicjatywa obywatelska ma 5 lat, 4.08, http://ec.europa.eu/poland/news/170804_ EIO_pl\#_ftn7, 7.08.2017.

Capik A. B., Gniewek A. (2012), Wprowadzenie do prawa Europejskiej Inicjatywy Obywatelskiej, Luksemburg, p. 39, http://www.iph.krakow.pl/images/do-pobrania/Publikacje/Europejska inicjatywa_obywatelska-B._Capik_A._Gniewek.pdf, 18.08.2017.

David Cameron says being PM 'the greatest honour' in final Downing Street speech, 13.07.2016, BBC News, http://www.bbc.com/news/uk-politics-36778350, 26.08.2017.

David Cameron zrzeka się mandatu. "Nie ma możliwości bycia skutecznym postem, kiedy było się wcześniej premierem”, 12.09.2016, https://wiadomosci.wp.pl/david-cameron-zrzeka-siemandatu-nie-ma-mozliwosci-bycia-skutecznym-poslem-kiedy-bylo-sie-wczesniej-premierem-6036245594460801a?ticaid=117ba6\&_ticrsn=3, 26.08.2017.

Hautala H. (2010), Wstęp, in: Podręcznik europejskiej inicjatywy obywatelskiej. Przewodnik po zasadach pierwszego ponadnarodowego narzędzia demokracji bezpośredniej na świecie, Green European Foundation, Bruksela.

Kitschelt H. P. (1986), Political Opportunity Structures and Political Protest: Anti-Nuclear Movements in Four Democracies, "British Journal of Political Science", vol. 16.

Klaus K. (2004), Pojęcie i źródła deficytu demokracji w UE, "Studia Europejskie” 2, pp. 53-71.

Korteweg R. (2015), Beware the four horsemen circling Europe: Greece, Russia, migrants and the Brexit, "The Independent", 24.06, http://www.independent.co.uk/voices/comment/beware-the-fourhorsemen-circling-europe-greece-russia-migrants-and-the-brexit-10343447.html, 25.08.2017.

Koruba K. (2017), Czym jest deficyt demokratyczny w UE?, 3.04, http://prawapolityka.pl/2017/04/ czym-jest-deficyt-demokratyczny-w-ue/, 15.08.2017. 
Kużelewska E. (2011), Proces ratyfikacji Traktatu ustanawiajacego Konstytucję dla Europy i jego nastęstwa, Oficyna Wydawnicza ASPRA-JR, Warszawa.

Kużelewska E. (2006), Referendum w procesie integracji europejskiej, ASPRA, Warszawa.

Łada A. (2016), Referendokracja. Czy referenda uczyniq Unię Europejska bardziej demokratyczna??, ISP, Warszawa.

Mizera K. (2014), Deficyt demokratyczny w Unii Europejskiej, "Folia Iuridica Wratislaviensis", vol. 3 (1).

Musiał-Karg M. (2014), Europejska inicjatywa obywatelska - uwagi na temat roli obywateli w procesie integracji europejskiej, "Rocznik Integracji Europejskiej”, nr 8.

Musiał-Karg M. (2012), Instytucje demokracji bezpośredniej w procesie integracji europejskiej-od referendum ogólnonarodowego do europejskiej inicjatywy obywatelskiej, "Rocznik Integracji Europejskiej", nr 6.

Musiał-Karg M. (2008), Referendum w państwach europejskich. Teoria, praktyka, perspektywy, Wydawnictwo Adam Marszałek, Toruń.

Musiał-Karg M., Lesiewicz E. (2015), Brytyjskie i greckie referenda a groźba Brexitu i Grexitu, "Przegląd Europejski", nr 3 (37).

Nentwich M. (1998), Opportunity structures for citizens' participation, in: Political Theory and the European Union. Legitimacy, constitutional choice and citizenship, eds. A. Weale, M. Nentwich, Routledge, London-New York.

Nentwich M. (1996), Opportunity Structures for Citizens'Participation: The Case of the European Union, European Integration online Papers (EIoP), vol. 0, no. 1, http://eiop.or.at/eiop/ pdf/1996-001.pdf, 17.08.2017.

Parliament passes Brexit bill and opens way to triggering article 50, 13.03.2017, https://www. theguardian.com/politics $/ 2017 / \mathrm{mar} / 13 /$ brexit-vote-article-50-eu-citizens-rights-lords-mps, 29.08.2017.

Piotrowicz D., Brytyjski eurosceptycyzm pod lupq, 8.06.2015, http://www.psz.pl/127-unia-europejska/brytyjski-eurosceptycyzm-pod-lupa, 22.08.2017.

Porozumienie UE z Wielkq Brytaniq, "Puls Biznesu", 20.02.2016, https://www.pb.pl/porozumienieue-z-wielka-brytania-822233, 26.08.2017.

Premier Wielkiej Brytanii zdradziła scenariusz Brexitu, 17.01.2017, http://www.newsweek.pl/swiat/ polityka/co-dla-wielkiej-brytanii-oznacza-brexit-,artykuly,403749,1.html, 26.08.2017.

Rada Europejska (art. 50) - wytyczne do negocjacji w sprawie Brexitu, 29.04.2017, http://www.consilium.europa.eu/pl/press/press-releases/2017/04/29-euco-brexit-guidelines/, 26.08.2017.

Queen's Speech 2015 EU referendum, tax freeze and right-to-buy, BBC News, http://www.bbc.com/ news/uk-politics-32894214, 5.08.2015.

Referenda akcesyjne na Malcie, w Stowenii i na Wegrzech, "Biuletyn Analiz UKIE", nr 11/2003, http://www.biuletyn.ukie.gov.pl, 17.03.2006.

Rezolucja Parlamentu Europejskiego z dnia 13 stycznia 2009 r. w sprawie perspektyw rozwoju dialogu obywatelskiego w ramach Traktatu z Lizbony (2008/2067(INI), Dz. Urz. UE 2010, $\mathrm{C} 46 / \mathrm{E} / 23$.

Sikorski Ł., Brexit-powrót do przeszłości. Wspomnienie referendum unijnego z 1975 r., 20.06.2016, http://www.emito.net/wiadomosci/wielka_brytania/brexit_powrot_do_przeszlosci_wspomnienie_referendum_unijnego_z_1975_r__2031655.html, 26.08.2017.

Sondaż: znaczny skok poparcia dla Brytanii w Unii Europejskiej, 21.02.2016, http://www.polskieradio.pl/5/3/Artykul/1584914,Sondaz-znaczny-skok-poparcia-dla-Brytanii-w-Unii-Europejskiej, 26.08.2017.

Stara dobra pułapka referendum europejskiego, 03.07.2013, http:/www.voxeurop.eu/pl/content/ article/2288311-stara-dobra-pulapka-referendum-europejskiego, 10.07.2016. 
Stawiski J., Pierwszy kraj, który opuści Unię? Groźba „Brexitu” i żadanie reform, 24.05.2015, TVN24 BiŚ, http://www.tvn24.pl/wiadomosci-ze-swiata,2/pierwszy-kraj-ktory-opusci-uniegrozba-brexitu-i-zadanie-reform,545081.html, 7.08.2015.

Sutton M. (2011), France and the Construction of Europe, 1944-2007: The Geopolitical Imperative, Berghahn Books, New York-Oxford.

Szymczyński T. R. (2007), Dylematy wokót instytucji referendum europejskiego, "Rocznik Integracji Europejskiej" nr 1.

Szymczyński T. R. (2008), Ireland, the Lisbon Treaty and the European Referendum, "European Governance", URGE, vol. 2, no. 2, July.

Szymczyński T. R. (2010), On Some Consequences of the Contemporary Shape of the European Referendum, in: The Road Europe Travelled Along. The Evolution of the EEC/EU Institutions and Policies, eds. D. Preda, D. Pasquinucci, Series: Euroclio, vol. 54, Bruxelles.

The Conservative Party Manifesto 2015. Strong Leadership. A Clear Economic Plan. A Brighter, More Secure Future, https://s3-eu-west-1.amazonaws.com/manifesto2015/ConservativeManifesto2015.pdf, p. 30.

Unię Europejskq czeka Brexit? Media: Referendum w Wielkiej Brytanii w 2016 roku (2015), TOK FM, http://www.tokfm.pl/Tokfm/1,130517,18428980, unie-europejska-czeka-brexit-mediawielka-brytania-wyjdzie.html, 26.08.2017.

Wilk-Reguła W., Brytyjczyków referendów w sprawie członkostwa w UE czyli czy można zjeść ciastko $i$ mieć ciastko?, http://wilkregula.natemat.pl/49345, brytyjczykow-referendow-w-sprawieczlonkowstwa-w-ue-czyli-czy-mozna-zjesc-ciastko-i-miec-ciastko, 8.07.2016.

\section{Annex 1}

Referenda on the matters of European integration

\begin{tabular}{|c|c|c|c|c|c|}
\hline & State & Date & Subject & Turnout (\%) & $\begin{array}{l}\text { Yes } \\
(\%)\end{array}$ \\
\hline 1 & 2 & 3 & 4 & 5 & 6 \\
\hline 1 & France & April 23, 1972 & EU enlargement & 60.27 & 68.28 \\
\hline 2 & Ireland & May 10, 1972 & EU membership & 70.88 & 83.1 \\
\hline 3 & Norway & Sept. 26, 1972 & EU membership & 79.2 & 46.5 \\
\hline 4 & Denmark & Oct. 02,1972 & EU membership & 90.14 & 63.29 \\
\hline 5 & Switzerland & Dec. 3, 1972 & EFTA membership & 52 & 72.5 \\
\hline 6 & Great Britain & June 05, 1975 & EC membership & 64.03 & 67.23 \\
\hline 7 & Greenland & Feb. 23, 1982 & EC membership & 74.91 & 45.96 \\
\hline 8 & Denmark & Feb. 27, 1986 & SEA - Single Market & 75.39 & 56.24 \\
\hline 9 & Ireland & May 26, 1987 & SEA - Single Market & 75.39 & 69.92 \\
\hline 10 & Italy & June 18,1989 & mandate for the EP & 85.4 & 88.06 \\
\hline 11 & Denmark & June 2, 1992 & Maastricht Treaty & 82.9 & 49.3 \\
\hline 12 & Ireland & June 18, 1992 & Maastricht Treaty & 57.3 & 69.1 \\
\hline 13 & France & Sept. 20, 1992 & Maastricht Treaty & 69.69 & 51.05 \\
\hline 14 & Switzerland & Dec. 6, 1992 & EEA membership & 78 & 49.7 \\
\hline 15 & Liechtenstein & Dec. 12, 1992 & EEA membership & 87 & 55.81 \\
\hline 16 & Denmark & May 18,1993 & $\begin{array}{l}\text { Maastricht Treaty } \\
\text { (with exclusions) }\end{array}$ & 85.5 & 56.77 \\
\hline 17 & Austria & June 12, 1994 & EU membership & 82.35 & 66.58 \\
\hline 18 & Finland & Oct. 16,1994 & EU membership & 70.4 & 56.88 \\
\hline 19 & Sweden & Nov. 13, 1994 & EU membership & 83.32 & 52.74 \\
\hline 20 & Aland Island & Nov. 20, 1994 & EU membership & 49.1 & 73.64 \\
\hline
\end{tabular}




\begin{tabular}{|c|c|c|c|c|c|}
\hline 1 & 2 & 3 & 4 & 5 & 6 \\
\hline 21 & Norway & Nov. 28, 1994 & EU membership & 89 & 47.8 \\
\hline 22 & Liechtenstein & April 9, 1995 & EEA membership & 82.05 & 55.88 \\
\hline 23 & Switzerland & June 8, 1997 & EU candidacy & 35 & 25.9 \\
\hline 24 & Ireland & May 22, 1998 & Amsterdam Treaty & 56.26 & 61.74 \\
\hline 25 & Denmark & May 28,1998 & Amsterdam Treaty & 76.24 & 55.10 \\
\hline 26 & Switzerland & May 21,2000 & bilateral agreements with the EU & 48 & 67.2 \\
\hline 27 & Denmark & Sept. 28,2000 & Adoption of the euro & 87.5 & 46.87 \\
\hline 28 & Switzerland & March 4, 2001 & EU candidacy & 55 & 23.2 \\
\hline 29 & Ireland & June 7, 2001 & Nice Treaty & 34.79 & 46.13 \\
\hline 30 & Ireland & Oct. 19,2002 & Nice Treaty & 49.47 & 62.89 \\
\hline 31 & Malta & March 8, 2003 & EU membership & 91 & 53.6 \\
\hline 32 & Slovenia & March 23, 2003 & EU membership & 60.3 & 89.6 \\
\hline 33 & Hungary & April 12, 2003 & EU membership & 45.6 & 83.7 \\
\hline 34 & Lithuania & May $10-11,2003$ & EU membership & 63.3 & 89.9 \\
\hline 35 & Slovakia & May $16-17,2003$ & EU membership & 52.2 & 92.4 \\
\hline 36 & Poland & June $7-8,2003$ & EU membership & 58.8 & 77.5 \\
\hline 37 & Czech Republic & June $13-14,2003$ & EU membership & 55.2 & 77.3 \\
\hline 38 & Estonia & Sept. 14, 2003 & EU membership & 64 & 66.8 \\
\hline 39 & Sweden & Sept. 14, 2003 & Adoption of the euro & 82.6 & 41.8 \\
\hline 40 & Latvia & Sept. 20, 2003 & EU membership & 72.5 & 67 \\
\hline 41 & Romania & Oct. 19, 2003 & $\begin{array}{l}\text { Amendment to the Constitution } \\
\text { (EU accession) }\end{array}$ & 55.2 & 89.6 \\
\hline 42 & Spain & Feb. 20, 2005 & Constitution for Europe & 42 & 76 \\
\hline 43 & France & May 29,2005 & Constitution for Europe & 69.37 & 45.33 \\
\hline 44 & Netherlands & June 1,2005 & Constitution for Europe & 62.8 & 38.4 \\
\hline 45 & Switzerland & June 5,2005 & Schengen Agreement & 56.63 & 54.63 \\
\hline 46 & Luxembourg & July 10,2005 & Constitution for Europe & 90.44 & 56.52 \\
\hline 47 & Switzerland & Sept. 25, 2005 & $\begin{array}{l}\text { Free flow of people - new EU } \\
\text { members }\end{array}$ & 54.51 & 55.98 \\
\hline 48 & Ireland & July 12,2008 & Lisbon Treaty & 53.1 & 46.6 \\
\hline 49 & Switzerland & Feb. 8, 2009 & $\begin{array}{l}\text { Free flow of people - Bulgaria } \\
\text { and Romania }\end{array}$ & 51.44 & 59.61 \\
\hline 50 & Switzerland & May 17, 2009 & $\begin{array}{l}\text { Schengen Agreement (biome- } \\
\text { tric passports and travel docu- } \\
\text { ments) }\end{array}$ & 38.77 & 50.15 \\
\hline 51 & Ireland & Oct. 2, 2009 & Lisbon Treaty & 59 & 67.1 \\
\hline 52 & Croatia & Jan. 22, 2012 & EU membership & 43.51 & 66.27 \\
\hline 53 & Ireland & May 31,2012 & Fiscal Pact & 50.53 & 60.37 \\
\hline 54 & San Marino & Oct. 20,2013 & EU accession negotiations & $\begin{array}{l}43.38 \text { (no qu- } \\
\text { orum } 32 \% \text { of } \\
\text { eligible voters } \\
\text { voted "Yes" }\end{array}$ & 50.28 \\
\hline 55 & Denmark & May 24, 2014 & $\begin{array}{l}\text { Accession to the United Patent } \\
\text { Court }\end{array}$ & 55.85 & 62.47 \\
\hline 56 & Greece & July 5,2015 & Accepting EU financial aid & 62.15 & 38.69 \\
\hline 57 & Denmark & Dec. 3, 2015 & $\begin{array}{l}\text { Enhanced collaboration with } \\
\text { the EU in the judiciary and in- } \\
\text { ternal matters }\end{array}$ & 72 & 46.89 \\
\hline 58 & Netherlands & April 6, 2016 & $\begin{array}{l}\text { Ratification of the Association } \\
\text { Agreement between the EU and } \\
\text { Ukraine }\end{array}$ & 32.3 & 38.2 \\
\hline
\end{tabular}




\begin{tabular}{||c|l|l|l|c|c||}
\hline 1 & \multicolumn{1}{|c|}{2} & \multicolumn{1}{|c|}{3} & \multicolumn{1}{c||}{4} & 5 & 6 \\
\hline 59 & Great Britain & June 23, 2016 & Brexit & 72.2 & 51.9 \\
\hline 60 & Hungary & Oct. 2, 2016 & $\begin{array}{l}\text { Agreement for compulsory re- } \\
\text { fugee quotas }\end{array}$ & 39.86 & 98.3 \\
\hline
\end{tabular}

Source: Own elaboration.

\section{Summary}

The practice of using direct democracy in the European Union's countries shows that 'European' issues have become an increasingly popular subject of public debate and then of referendum votes. The use of national referenda in deciding on European integration process is not a new phenomenon - the first referendum on this subject was held in 1972. Since then European integration has been the subject of sixty popular votes - in EU member states, candidate states and in third countries. It can be said that the majority of experience related to direct democracy in the EU is rather positive, but there have been some votes that have brought serious problems to the European Union. One such example is the British referendum of 2016 on further membership of the EU. This referendum provoked a huge debate on the future shape of the Community and the further directions of integration in Europe.

The main objective of this paper is to answer the question of the impact of European referenda on the future shape of the EU (with particular attention paid to the 2016 referendum on Brexit).

Key words: referendum, direct democracy, European integration, European Union, Brexit

\section{Referendum jako instytucja wpływania na przyszłość zjednoczonej Europy. Brexit a ksztalt Unii Europejskiej}

\section{Streszczenie}

Praktyka wykorzystania form demokracji bezpośredniej w państwach europejskich dowodzi, iż prócz licznych głosowań referendalnych w sprawach ogólnonarodowych, coraz bardziej popularnym przedmiotem debaty publicznej, a następnie głosowania stają się również kwestie o tematyce „unijnej”. Wykorzystanie referendum ogólnonarodowego do decydowania w sprawach procesu integracji europejskiej nie jest zjawiskiem nowym, bowiem pierwsze głosowanie o tej tematyce miało miejsce już w 1972 r. Od tego czasu integracja europejska stała się przedmiotem 60 ogólnonarodowych referendów - zarówno w państwach członkowskich, w państwach kandydujących, jak i w państwach ,trzecich”, które związane są dziś z Unią Europejską różnego rodzaju umowami bilateralnymi. Większość doświadczeń związanych z wykorzystaniem referendów w sprawach „europejskich” jest - można rzec - pozytywnych, jednak część z nich przysporzyło państwom członkowskim i samej Unii wielu problemów. Jednym z ostatnich przykładów głosowań referendalnych, którego konsekwencje będą miały swój wyraz w przyszłym kształcie Unii Europejskiej, jest głosowanie z 23 czerwca 2016 r. sprawie członkostwa Wielkiej Brytanii w UE.

Głównym celem niniejszego tekstu jest odpowiedź na pytanie o konsekwencje referendów w sprawie integracji (ze szczególnym uwzględnieniem głosowania brytyjskiego) dla przyszłego kształtu Unii Europejskiej.

Słowa kluczowe: referendum, demokracja bezpośrednia, integracja europejska, Unia Europejska, Brexit 